\title{
LOCAL AND GLOBAL: MESOGOVERNMENTS AND TERRITORIAL IDENTITIES
}

\section{Luis Moreno}

This article deals primarily with the interaction between the local and the global, the revival of territorial identities, and the increasing incidence of the meso-level in contemporary life. The focus on territoriality should not be considered as the neglect of other forms of societal identities also affected by globalization. However, our main area of analysis concerns identity and territory.

At the turn of the millenium, citizens face a situation of advanced modernity with some perplexity. They have discovered new horizons in the understanding of their own collective and individual life within a climate of uncertainty and rapid change. To a large extent, all these transformations have been made possible by the telecommunications revolution.

Nowadays, individuals and groups have immediate access to a wide range of endless data, information, and news generated in the remotest corners in the earth. The integrated networks of personal computers, TV terminals, and Web servers allow for a reciprocal and fluid communication between the house or workplace and the multifaceted external world. ${ }^{1}$ One consequence of these technological developments is the higher degree of democratization in the processes of dissemination and exchange of information.

A myriad of facts, including those related to cultures and collectives all over the world are now available to the general public. The 'digestion' of such avalanches of information increasingly conditions economic, political, and social activities. The restriction of information and representation images characteristic of power practices in the past has been progressively replaced by the efficient management of overwhelming masses of information produced swiftly and without restraint.

In parallel, the growing attachment of citizens to communities at local and meso-level is also noticeable, particularly in Europe. Such communities are of rather analogous socio-economic characteristics and are politically situated in a somewhat equidistant position between the nation-state (or multinational state), and other transnational bodies and institutions (ASEAN, EU, GATT, G-7, IMF, NAFTA, NATO, WB, WTO). 
Territorial identities associated with these communities have provided new political underpinnings for citizens and groups.

The rebuilding of relationships between the in- and out-spheres of human existence is shaped by citizens' internalization of practicalities and values related to a global context affecting matters of everyday life. Identities are in the midst of such a process of re-definition, with crucial derivations for political culture, social mobilization, and political institutions. The most important factor in all aspects of globalization can be considered as perceptive. ${ }^{2}$ Interpretations claiming that a blurring of local markers would follow the globalizing trends should nevertheless be qualified. In fact, we are witnessing a reinforcement of community identities at the sub-state level, a trend counteracting the simple assumption of a dehumanizing and undemocratic Brave New World.

Attachments to supranational identities should also be accounted for, as the process of Europeanization clearly shows. This multiplicity of identities is reflected in the way that electors cast their votes. Therefore, patterns of electoral behavior should be regarded not only as the result of a combination of ideological offerings, party programs and leadership, but also as the manifestation of 'tactical voting' depending on the territoriality related to the election (municipal, regional, national, supranational).

In the first section of this article a conceptual review of ideas and theoretical assumptions is carried out. Ethnoterritoriality, collective identities, and the territorial accommodation in plural societies are among the concepts analyzed. In the second section, a reflection on the implications of globalization, the extension of market values, and the relative loss of power and influence by the nation-state is put forward. The last section of this article focuses on the growing role played by those mesolevel communities in Europe which have been able to make the general and the particular compatible. This development seems to be in line with a trend towards what can be labeled as a new cosmopolitan localism.

\section{Premises and concepts}

At present, all-embracing and exclusive identities are openly questioned and have become problematic. While being corroded by the forces of globalization they are also subject to fragmentation, competition and overlapping elements of a multiple 
and diverse nature. The discontinuity and dislocation of social arrangements enable diverse identities - particularly, territorial - to relate to each other in quite an unpredictable manner. In fact, identities are shared in various degrees by individuals and are subject to constant internalization by group members. ${ }^{3}$

A considerable problem arises when establishing boundaries and degrees of citizens' self-identification, and on interpreting the causes for political mobilization related to territorial identities. As pointed out earlier, a strengthening of meso-level identities goes hand in hand with a growing attachment to supranational levels of civic membership and institutional development. The process of Europeanization seems to conciliate adequately supranational, state and local identities in apparent conflict among themselves ${ }^{4}$.

In this article we deal primarily with the concept of ethnoterritoriality, which refers to a dimension where conflicts and political mobilizations are developed and have as their chief social actors those ethnic groups which possess a geographical underpinning. Such a spatial reference is identifiable within the boundaries of a polity, usually of a compound or plural composition. ${ }^{5}$

In plural societies individuals are tied to cultural reference groups which might be in competition among themselves. ${ }^{6}$ This results in a multiplicity of dynamic and often shared socio-political identities, which are not necessarily expressed explicitly. Therefore, identity markers are malleable, and the intensity of their manifestation greatly depends upon contingent circumstances. ${ }^{7}$

The revival of ethnoterritorial political movements in the Western world has coincided with an increasing challenge to the centralist model of the unitary state. Within the European context, Spain offers a good example of how regional devolution and federalization seek to articulate a response to the stimuli of the diversity of society. This plurality comprises cultural/ethnic groups with differences of language, history and traditions, which can also be reflected in the party system. ${ }^{8}$

Citizens in multinational states in Europe incorporate in variable proportions, both local/ethnoterritorial and state/national identities. The degree of internal consent and dissent in these plural polities has in the concept of dual identity a useful methodological tool for socio-political interpretations. ${ }^{9}$

Indeed, the quest for self-government by meso-level communities is in full accordance with the variable manifestation of such duality in citizens' self-identification: the more the primordial ethnoterritorial identity prevails upon modern state identity, the 
higher the demands for political autonomy. Conversely, the more characterized the state-national identity is, the less likely it would be for ethnoterritorial conflicts to appear. At the extreme, complete absence of one of the two elements of dual identity would lead to a socio-political fracture in the pluriethnic state, and demands for selfgovernment would probably take the form of independence. In other words, when citizens in a sub-state community identify themselves in an exclusive manner, the institutional outcome of such antagonism will also tend to be exclusive.

This article sustains the view that ethnoterritorial co-operation and agreement may not only overcome conflicts and divergence within plural polities, but can also provide a deepening of democracy by means of favoring the participation of citizens at all possible levels of institutional life and political decision-making. Such developments usually fit better in multinational polities where internal ethnoterritorial and cultural diversity are politicized and where citizens share dual identities (state national and ethnoterritorial regional).

The social sciences have also been exposed to the effects brought about by the informational revolution. Changes generated by globalization have underlined the obsolescence of a good deal of their analytical, conceptual, and methodological tools. Let us remember, however, that during the last decades the contributions of some social scientists created no little confusion when reflecting on socio-political rights and territorial identities.

Influential theories developed by North-American social scientists have frequently concentrated on the description and prescription of social categories having as referential contexts those of the USA and Canada. Some of these approaches - with universalistic pretensions - have impinged upon interpretations made by other academics around the world in a rather spurious manner.

Functional diffusionism, in particular, has persistently conveyed the idea that internal territorial differences within nation states would disappear with the extension of liberal democracy and industrial capitalism. As communication of political, economic and cultural matters increased, the peoples of different regions would develop a new common identity, which would transcend their differences. ${ }^{10}$ Society would became 'modernized' by means of elite-initiated policies aimed at achieving social standardization (e.g. common language and citizenship). As a consequence, the cultural identities of ethnic groups and minorities would be replaced by a set of class-orientated conflicts, or conflicts among interest groups. Thus, modernization 
was regarded to have brought about the idea of an all-embracing state national identity rooted in both cultural and civic axes. History has repeatedly falsified such analyses. ${ }^{11}$

Likewise, it has been argued that political accommodation to secure political and institutional stability in pluriethnic societies or polyarchies is almost impossible. Furthermore, attempts made to achieve such a goal are bound to result in either the break-up of the state or the consolidation of a type of hegemonic authoritarianism for the control of the state's unity. ${ }^{12}$. Contemporary liberal thinkers have greatly revitalized the debate regarding individual and collective rights. Most of them can be labeled 'liberal nationalists'. ${ }^{13}$ Some have argued persuasively for the case of multiculturalism and the politics of recognition for minorities. ${ }^{14}$ However, some of their normative analyses insist upon the unfeasibility of accommodating ethnonational groups within federations -as the case of Quebec and Canada would illustrate. ${ }^{15}$

Advocates of the American School of Comparative Politics had interpreted that the processes of periphery migrations into the urbanized core areas would eliminate the old local ascribing identities in favor of new associative links of a functional nature. Some of these theses advanced by Talcott Parsons y Karl Deutsch were often accepted uncritically and rather dogmatically. Thus, many North-American social scientists have adopted the view that universal progress requires a kind of assimilationist integration, which implies inclusive social systems and the practices of de-tribalization. ${ }^{16}$

The refutation of the referred-to theories and the analysis of complex political developments have stimulated social scientists to elaborate new frameworks for the understanding and explanation of contemporary social life. Neoinstitutionalism can be regarded as an approach aimed at a conceptual and analytical aggiornamento carried out mainly by North-American academics. There are three main variants within this school of thought: sociological, rational choice, and historical. All three share the view that institutions shape the preferences and objectives of social actors in their decision-making processes. Furthermore, they argue that through the establishment of the 'game rules' of power and influence, institutions also condition decisively the outcomes of such decisions. ${ }^{17}$

The enthusiasm shown by many European social scientists for the neoinstitutionalist theses is remarkable. Let us, however, acknowledge the fact that in the Old Continent institutions have secularly shaped decisions and identities, and 
vice-versa. This has been somewhat different in the case the New Continent, a fact that greatly explains the importance given by this new school of thought to the paramount role to be played by the institutions. Other routes for further research should be encouraged. For example, much explanatory work needs to be accomplished for the understanding of the mechanisms of interaction between human affinities and institutions. On explaining ethnoterritorial mobilization the dilemma between reasons and emotions reaches a level of inextricable categorical and conceptual de-construction. The reference to institutions as important sources for determining collective expectations and choices is useful but insufficient. Phenomena affecting ethnic relations are often a-rational. Groups with territorial identities are actors that do not necessarily behave according to any pre-determined institutional logic. Group solidarity and self-perception of comparative grievances, for instance, can be identified as powerful instruments for mobilization without any objective reasons based on empirical evidence or any particular pattern of institutional design.

\section{Globalization, market values and the nation-state}

At a time when certain universal visions of human existence seemed to indicate a fusion of both individuality and globality, group specifities have returned to the fore as main protagonists of social life. Other alternative views have envisaged a process of transit to a post-modern relativism. All things considered, citizens around the world are working to revive old particularities and communal roots. In this way spatial references multiply so that their social existence can be legitimized through a reassertion of collective identities.

Ethnic myths and group affiliations continue to offer a substratum for the management of individual anxieties and aspirations. In particular, European societies seem to reinforce secular ties of integration within the family, or to recreate mediumsized political communities as was the case in the early Modern Age. ${ }^{18}$

However, divergent effects resulting from the gradual configuration of the global village advanced by Marshall McLuhan ${ }^{19}$ can be observed. In the first place, the globalization and internationalization of trade encouraged by the telecommunication revolution are decisively affecting the economy worldwide, and have brought about a deep restructuring of contemporary capitalism. Other related 
developments have led some authors to point out that we are witnessing the emergence of a net society characterized by the exchange of transactions of an informational nature ${ }^{20}$.

Indeed, the constitution of a world market for communication schemes has been spectacular in recent times (NB. Between 1984 and 1995 it increased five-fold). At the beginning of 1996 there were 15 phone companies with revenues over US $\$ 10,000$ per year, an amount higher than the annual budgets of most small nation-states around the world. Furthermore, the use of new systems of interpersonal communication, such as electronic mail, has become almost universal in areas like the academic sector.

The Internet and the World Wide Web have become part of everyday life. Their presence is evident not only in corporate and professional realms, but also as regards a wide range of leisure activities. The younger generation is increasingly adopting new lifestyles, which are greatly influenced by the use of hypertext software for personal computers and related developments. Obviously, this informational advance reproduces the traditional dualities of 'insiders' and 'outsiders', but access to the new telecommunications is not confined to a few. In fact, the consumption costs are affordable to the majority of users. Easy accessibility and availability have greatly contributed to the dissemination of all kinds of information.

Some authors hold the view that the TV will remain the primary medium in shaping peoples' behavior and expectations ${ }^{21}$. They believe that the use of Internet will reach a saturation point in the not too long distant future. The homo videns will therefore remain the central subject in the global village/s. An alternative view sustains that the major factor in overcoming the cognitive constraints produced by TV high consumption is precisely the interactive nature of Internet. Note that in the period of 3 years, access to the Internet in the USA has reached 60 million households, the same market penetration that took TV a period of 15 years. By the year 2005 it is estimated that Internet traffic will be higher than the use of the traditional telephone. This trend seems to reaffirm the view that one multi-function terminal in the household will soon provide a versatile access to various means of communication, including TV and Internet.

The other visible side of the coin concerning our discussion relates to territorial identities, the political aspirations for political autonomy of medium-sized communities, and the relative obsolescence of the nation-state as the central arena 
for economic, political, and social life. In fact, the nation-state can be regarded as just another actor -on many occasions with a supporting or secondary role- in what some authors have labeled the New World Order, $I n C^{22}$. Often, its passivity turns into inefficacy when dealing with transnational criminal rackets. These groups are well suited operating at international level and are able to maximize the inability of individual nation-states to clamp down on organized crime ${ }^{23}$.

At present, national economic policies are becoming more and more dependent on external factors and constraints beyond their control. But geographical mobility does not solely affect capital flows. Other production factors are also concerned, such as industrial components and parts manufactured in cheap-labor countries and imported subsequently for assembling, marketing, and sale in core industrial countries. International freight and a legion of stateless managers are other factors, which are becoming increasingly transnational. ${ }^{24}$

Globalization has meant a transfer of authority and power from the nation-states to the markets. The very patterns of economic competition are to comply with the new rules of global markets and the strategies of transnational corporations. Is global capitalism deprived of any sense of territoriality? On selecting locations for investment, financial analysts consider first and foremost the level of profit that they expect to achieve. Indeed, they have a much wider perspective than that determined by purely national interests. ${ }^{25}$ But there are other crucial elements related to levels of social cohesion, the absence of political turmoil, or the stability of the institutions of the candidate countries which also need to be assessed. Other cultural aspects, such as educational systems or national languages are important too. Furthermore, the processes of decision-making for investments are greatly exposed to the input made by the media and opinion leaders, neither of which can be considered territorially 'neutral'.

National governments still maintain their nominal sovereignty empowering them to negotiate new economic frameworks (MERCOSUR, NAFTA, UEM, or WB). At the same time they also bargain with the transnational corporations. Their economic maneuvering to put forward innovative polices outside global demands is rather limited. The case of the programs for indicative planning implemented by the first Mitterrand Government in the early 1980s was symptomatic of the external constraints posed on the national sovereignty in the most statist country in Europe. 
French Governments after the Second World War put into action plans for economic growth. These were to be implemented in a hierarchical manner by the powerful French public sector, and were 'indicative' of the industrial priorities to be taken by private businesses. They set economic guidelines for the general development of the country. The model worked satisfactorily in the post-war period allowing the French economy to perform at a good level. Right after the Socialist victory in the 1981 General Election, the Mauroy Government attempted a different path away from the policies of economic austerity followed by the neighboring European countries. The aim was to overcome the effects of the lower stages of the economic cycle by means of implementing Neo-keynesian programs of re-activation. The experience ended in failure. In those years the majority of European countries had opted for programs of austerity and a tight control of their national deficits. International financial markets had overwhelmingly validated these measures. Not long after their initial implementation French economic policies suffered a Copernican turn and were to align themselves with the course of action taken by the rest of Europe.

Together with the limits posed upon nation-states' sovereignty by the internationalization of the financial markets, the regions and large cities have also exerted pressure on central governments for decentralization and autonomy. Both actions are having great repercussions on the power and auctoritas of the nationstate. Frequently, sub-state mesogovernments and local authorities do not require the rationalizing intervention of central bureaucracies and élites. In fact, the rules of the New World Order, Inc. often directly concern the action and policies of these substate layers of governments. They can activate policies of industrial relocation or attraction of foreign capitals without the role of the intermediaries at the state's center. By means of local incentives, urban re-development plans, or favoring corporatist agreements with trade unions and industrialists, mesogovernments and metropolitan authorities can have direct negotiations with the transnational corporations involved.

Mesogovernments as actors of political mobilization

Given this context of internationalization, the role played by medium-size polities is acquiring relevance in most aspects of contemporary life. The renewal of community 
life at the meso-level derives mainly from the combination of two main factors: a growing rejection of centralization in unitary states coupled with a strengthening of supranational politics, and a reinforcement of local identities and societal cultures with an territorial underpinning.

Mesogovernments are no longer dependent on the state building programs of rationalization carried out during the XIX and XX centuries. Meso-level entrepreneurs, social leaders and local intelligentsia have adopted many of the initiatives and roles once reserved for 'enlightened' élites, who in the past held the reins of power at the center of their nation states. Positions of influence are now more evenly distributed in central, meso-level and local institutions. Besides, the cooption of regional elites to the central institutions of government is no longer the exclusive route available to 'successful' political careers.

The supranational framework provided by the European process of convergence brings with it a 'new' element of further cosmopolitanism to mesocommunities and conurbations. At one point, and in the face of hard economic competition from other world regions, some analysts proposed the very idea of a 'fortress Europe'. According to this view, the secession from the international world arena would preserve the maintenance of the European welfare regimes. An economic 'wall' around EU member states would guarantee the social rights achieved by generations of Europeans. It would also stimulate a balanced growth, which, in turn, would create new employment coupled with job-sharing and the reduction of working time. Immigration would be tightly regulated. Undoubtedly this option would mean a U-turn in the cosmopolitan approach of the European culture and a radical mutation in its value-system. Besides, the current level of Europeanization makes the establishment of a strategy for achieving a monolithic autarchy unfeasible. Thus, the very idea of a 'fortress Europe' cannot be embraced as a workable scheme.

What is acquiring major relevance in the political life of Europe is the role of meso-level communities. Among others, two factors can be identified as having greatly contributed to enhance their significance: (a) The re-assertion of territorial identities, and (b) The implementation of the principle of subsidiarity. Let us briefly review both elements:

(a) The reinforcement of local identities has provided civil societies with a more participative and active role. Examples in Western Europe do not circumscribe 
to electoral deviations from national patterns (CiU-Catalonia, CSU-Baviera, LegaNorthern Italy, SNP-Scotland). Social movements and local entrepreneurs have found a more flexible context for action. Central state apparatuses are often clumsy and inefficient in dealing with bottom-up initiatives. Thus, conurbations and metropolitan areas are well equipped for some innovation policies in a more adaptable context to the changing needs laid down by the Information Age. The region of Brussels, Metropolitan Madrid, Greater London, and Paris and its urban satellites, are re-creating local civic cultures alongside their cosmopolitan traditions. Despite the lack of single identities or ethnic uniformities, these conurbations are in a similar position to other meso-level communities (regions and minority nations) as regards running their own affairs, and developing their potentialities outside the dirigiste control of the central state institutions. ${ }^{26}$

Many signs seem to point towards the rise of a European type of communitarianism, which should be regarded in quite a distinct fashion from that prescribed in North America for local communities ${ }^{27}$. In the case of the USA, many of the communitarian experiences may be regarded as reactions to specific social cleavages and pressing social fractures (the criminalization of social life), as an instrumental means of socialization in response to urban constriction (suburban isolationism), or as alternative lifestyles to dominant values (possessive individualism). From this perspective North-American communitarianism can be seen mainly as socially defensive. ${ }^{28}$

In the EU, territorial identities are mainly pro-active. They are not mere mechanisms of response for controlling the informational avalanche generated by the telecommunications revolution. The reinforcement of sub-state territorial identities is deeply associated with powerful material and symbolic referents of the past (culture, history, territories). They seem to have engaged in a process of innovation departing from a common ground, and which seeks to overcome the de-naturalizing effects of global hypermodernity. ${ }^{29}$ However, their manifestations do not take refuge in a reactive parochialism. They emerge, therefore, as 'project identities' characterized by pro-active attitudes. ${ }^{30}$

(b) The principle of subsidiarity was enshrined in the Treaty of European Union of 1992, known as the Treaty of Maastricht. It provides for decisions to be taken transnationally only if local, regional or national levels cannot perform better. In other words, the preferred locus for decision-making is that closer to the citizen, and as 
local as possible. State political elites, reluctant to further the process of European institutionalization, interpreted the subsidiarity principle as a safeguard for the preservation of traditional national sovereignty and, consequently, the powers to intervene centrally. The case of the United Kingdom is paradigmatic in this respect. According to such interpretations, the legislative supremacy of Westminster would be preserved from supranational intervention and regulation originated at the 'federal' institutions of the European Union. However, the devolution of power from the center of the British state to the constituent nations of the UK, and to amalgamated local authorities like the former Greater Council of London, could not be denied taking into account the same argumentative grounds.

The rationale implicit in the principle of subsidiarity favors the participation of sub-state layers of government in the running of public affairs, although global ones are also to be taken into account. At the same time, it encourages intergovernmental co-operation on the assumption that the role of the national states is to be less hierarchical than its has been up until now. Territorial identities are intertwined in a manner that expresses the degrees of citizens' loyalties towards the various sources of political legitimization: municipalities, regions, nations, states, and European Union. Accountability and territorial institutions should therefore reflect the political expression of people's identities and democratic participation.

Immigration from non-EU countries has certainly had an impact on the growing feelings of xenophobia in Europe. Nevertheless, immigrants who are willing to take on those values of civic pluralism and tolerance find no major difficulty of integration in the economic and social life at their first 'port of entry', i.e. local and meso-level communities.

\section{Conclusion: a new cosmopolitan localism}

The processes of bottom-up transnationalization and top-down devolution of powers have allowed a considerable extension of a type of European cosmopolitan localism. This is reflected in both societal interests, which are aimed at developing a sense of local community and at participating simultaneously in the international context. There is, thus, a growing adjustment between the particular and the general.

European cosmopolitan localism mainly concerns medium-sized polities within or without the framework of a state. Thus, it can be detected in minority nations 
(Catalonia, Scotland), small nation-states (Czech Republic, Luxembourg, Slovenia), but also in regions and metropolitan areas (Languedoc, Brussels, Berlin, Milan). The latter, in particular, seem to follow a pattern of re-creating those political communities which flourished in the age prior to the New World discoveries (Italian city-states, Hanseatic League, principalities). However, and in contrast with the Renaissance period, there is now a common institutional tie inherent in the process of Europeanization. The majority of the EU peoples have internalized European institutions, albeit rather loosely and gradually. The European Court of Justice, the Schengen Agreement, and the inception of the Euro currency can be regarded as steps advancing firmly towards the very idea of European transnationalization. Even areas such as those concerning social policy and welfare development -the traditional domain of national intervention - are viewed gradually from a supranational perspective ${ }^{31}$.

Needless to say, all these processes in Europe are taking place in a period of relatively stable economic growth characterized by the absence of wars between the once powerful colonial nation-states. Some authors hold the view that together with globalization the potential for a pessimistic scenario is just around the corner. The ever-latent possibility of rivalries between the nation-states, trade conflicts between world regions, or the growth of religious fundamentalism and xenophobia are potentially explosive ${ }^{32}$. Alternatively, a move towards a new form of civilization capable of revitalizing the old federalist congruence between unity and diversity by means of political pacts appears to be a reasonable challenge for this emerging cosmopolitan localism.

Bibliographical references

Anderson, Benedict (1983), Imagined Communities: Reflections on the Origins and Spread of Nationalism. London: Verso.

Barth, Fredrik (ed.) (1969), Ethnic Groups and Boundaries. The Social Organization of Culture Difference. Boston: Little, Brown \& Co.

Brass, Paul (1991), Ethnicity and Nationalism. Theory and Comparison. New Delhi: Sage. 
Castells, Manuel (1997) The Information Age: Economy, Society and Culture. Volume II: The Power of Identity. Cambridge, Mass.: Blackwell.

Chomsky, Noam (1994), World Orders, Old and New. London: Pluto.

Coakley, John (1992), 'Conclusion: Nationalist Movements and Society in Contemporary Western Europe' in Coakley, John (ed.), The Social origins of Nationalist Movements, pp. 212-230. London: SAGE/ECPR.

Cohen, Anthony (1992), The Symbolic Construction of Community (1st Ed.: 1985. London: Routledge.

Connor, Walker (1984), The National Question in Marxist-Leninist Theory and Strategy. Princeton, N.J.: Princeton University Press.

Connor, Walker (1994), Ethnonationalism. The Quest for Understanding. Princeton, N.J.: Princeton University Press.

Conversi, Daniele (1997), The Basques, The Catalans and Spain. Alternative Routes to Nationalist Mobilisation. London; C. Hurst \& Co.

Dahl, Robert (1971), Polyarchy, Participation and Opposition. New Haven, Conn.: Yale University Press.

Deacon, Bob; Husle, Michelle and Paul Stubbs (1997), Global Social Policy. International Organizations and the Future of Welfare. London: Sage.

Deutsch, Karl (1966), Nationalism and Social Communication (2nd De.). New York: M.I.T. Press.

Esman, Milton J. (ed.) (1977), Ethnic Conflict in the Western World. Ithaca, NY: Cornell University Press. 
Etzioni, Amitai (1993), The Spirit of Community. Rights, Responsibilities, and the Communitarian Agenda. New York: Crown.

Gagnon, Alain-G. (ed.) (1993), Quebec: State and Society. Scarborugh, Ont.: Nelson.

Gellner, Ernest (1983), Nations and Nationalism. Ithaca, N.Y.: Cornell University Press.

Giddens, Anthony (1991), Modernity and Post-Modernity: Self and Society in the Late Modern Age. Cambridge: Polity Press.

Glazer, Nathan and Moynihan, Daniel (1963), Beyond the Melting Pot. Cambridge, MA.: M.I.T \& Harvard University Press, 1963.

Greenfeld, Liah (1992), Nationalism. Five Roads to Modernity. London: Harvard University Press.

Greider, William (1997), One World, Ready or Not: The Manic Logic of Global Capitalism. New York. Simon \& Schuster.

Hobsbawm, Eric (1990), Nations and Nationalism since 1780: Programme, Myth and Reality. Cambridge: Cambridge University Press.

Horowitz, Donald (1985), Ethnic Groups in Conflict. Berkeley, CA.: University of California Press.

Keating, Michael (1996), Nations Against the State: The New Politics of Nationalism in Quebec, Catalonia and Scotland. London: Macmillan.

Kilminster, Richard (1997), 'Globalization as an Emergent Concept', in Alan Scott (ed.), The Limits of Globalization. London: Routledge, pp. 257-283.

Koelble, Thomas (1995), 'The New Institutionalism in Political Science and Sociology', Comparative Politics, Vol. 27, No. 2, pp. 231-243. 
Kymlicka, Will (1995), Multicultural Citizenship: A Liberal Theory of Minority Rights. Oxford: Oxford University Press.

Linz, Juan (1973), 'Early State-Building and the Late Peripheral Nationalisms against the State: the case of Spain', in Samuel Eisenstadt and Stein Rokkan (eds.), Building States and Nations: Models, Analyses and Data across Three Worlds. Beverly Hills, CA.: Sage, pp. 32-116.

(1975), 'Politics in a Multi-Lingual Society with a Dominant World Language: The case of Spain', in Jean-Guy Savard and Richard Vigneault (eds.), Les états multilingues: problems et solutions. Québec: Les Presses de l'Université Laval, pp. 367-444.

Linz, Juan (1997), 'Democracy, multinationalism and federalism'. Paper resented at the IPSA World Congress, Seoul.

McLuhan, Marshall (1964), Undersatnding Media. The Extensions of Man. New York: McGraw-Hill.

McLuhan, Marshall and Fiore, Quentin (1967), The Medium is the Massage. An Inventory of Effects. New York: Bantam Books.

Melucci, Alberto (1989), Nomads of the Present. London: Hutchinson Radius.

Moreno, Luis (1986), Decentralisation in Britain and Spain: The cases of Scotland and Catalonia. Ph.D. thesis, University of Edinburgh.

Moreno, Luis (1995), 'Multiple Ethnoterritorial Concurrence in Spain', Nationalism and Ethnic Politics, Vol. 1, No. 1, pp. 11-32.

Moreno, Luis (1997a), La federalización de España. Poder político and territorio. Madrid: Siglo XXI.

Moreno, Luis (1997b), Federalism: The Spanish Experience. Pretoria: HRSC: 
Moreno, Luis and Ana Arriba, (1996), 'Dual Identity in Autonomous Catalonia', Scottish Affairs, No. 17, pp. 78-97.

Moreno, Luis; Arriba, Ana, and Araceli Serrano (1998), 'Multiple Identities in Decentralized Spain: The Case of Catalonia', Regional and Federal Studies, Vol,. 8, No.3.

Myrdal, Gunnar (1957), Economic Theory and Underdeveloped Regions. London: Duckworth.

Pérez-Agote, Alfonso (1994), 'Un modelo fenomenológico-genético para el análisis comparativo de la dimensión política de las identidades colectivas en el Estado de las Autonomías', in Justo G. Beramendi, Ramón Máiz and Xosé M. Núñez (eds.), Nationalism in Europe. Past and Present. Santiago de Compostela: Universidad de Santiago, pp.307-323.

Perroux, François (1964), L'Economie du Xxe Siècle. Paris: Presses Universitaires de France.

Rudolph, Jr., Joseph R. and Robert J. Thompson (1989), Ethnoterritorial Politics, Policy and the Western World. Boulder, CO.: Lynne Rienner.

Safran, William (1987), 'Ethnic Mobilization, Modernization, and Ideology: Jacobinism, Marxism, Organicism and Functionalism', The Journal of Ethnic Studies, Vol. 15, NO. 1, pp. 1-31.

Sartori, Giovanni (1997), Homo videns. Rome: Gius, Laterza \& Figli Spa.

Schmidt, Vivien A. (1995), 'The New World Order, Incorporated: The Rise of Business and the Decline of the Nation-State", What Future for the State?, Daedalus, Vol. 124, No. 2, pp. 75-106.

Smith, Anthony (1991), National Identity. London: Penguin. 
Strange, Susan (1995), 'The Limits of Politics', Government and Opposition, Vol. 30, No. 3, pp. 291-311.

Tamir, Yael (1993), Liberal Nationalism. Princeton, N.J.: Princeton University Press.

Taylor, Charles (1992), Multiculturalism and 'The Politics of Recognition': an essay. Princeton, N.J.: Princeton University Press.

Walzer, Michael (1997), On toleration. New Haven, Conn.: Yale University Press.

Wallerstein, Immanuel, The Modern World-System: Vol. 1 (1974): Capitalist agriculture and the origins of the European world-economy in the sixteenth century. New York: Academic Press; Vol. 2 (1980); Mercantilism and the consolidation of the European world-economy, 1600-1750. New York: Academic Press; Vol. 3 (1989), The second era of great expansion of the capitalist world-economy, 1730-1840s. New York: Academic Press.

Wallerstein, Immanuel (1984), 'Household Structures and Labor-force Formation in the Capitalist World-Economy', in Joan Smith, Immanuel Wallerstein and Hans-Dieter Evers (eds.), Households and the World Economy. Beverly Hills: Sage, pp. 17-22.

\section{NOTES}

${ }^{1}$ The growing importance of households as 'part and parcel' of the world economy, and as basic units of production, is to be underlined. See Wallerstein, Immanuel, 'Household Structures and Labor-force Formation in the Capitalist World-Economy', in Joan Smith, Immanuel Wallerstein and Hans-Dieter Evers (eds.), Households and the World Economy (Beverly Hills: Sage, 1984) pp. 17-22.

2 Strange, Susan (1995), 'The Limits of Politics', Government and Opposition, Vol. 30, No. 3 (1995), pp. 291-311.

3 On this issue, see Melucci, Alberto, Nomads of the Present. (London: Hutchinson Radius, 1989), Giddens, Anthony, Modernity and Post-Modernity: Self and Society in the Late Modern Age (Cambridge: Polity Press, 1991), Smith, Anthony, National Identity (London: Penguin, 1991), and Greenfeld, Liah (1992), Nationalism. Five Roads to Modernity (London: Harvard University Press, 1992).

${ }^{4}$ Some authors are of the opinion that despite the fact that two identities can be referred to a larger entity it does not preclude their possible relationship of incompatibility —-see Pérez-Agote, Alfonso, 'Un 
modelo fenomenológico-genético para el análisis comparativo de la dimensión política de las identidades colectivas en el Estado de las Autonomías', in Justo G. Beramendi, Ramón Máiz and Xosé M. Núñez (eds.), Nationalism in Europe. Past and Present (Santiago de Compostela: Universidad de Santiago) p. 311. That would be the case, for example, of both Basque and Spanish exclusive forms of selfidentification. However, the subsuming of those identities under the European confines implies a nexus -even though it is not explicitly sought- of congruence between both exclusive forms of selfidentification.

${ }^{5}$ On the concept of ethnoterritoriality, see Rudolph, Jr., Joseph R. and Robert J. Thompson (eds.), Ethnoterritorial Politics, Policy and the Western World (Boulder, CO.: Lynne Rienner, 1989); Coakley, John, 'Conclusion: Nationalist Movements and Society in Contemporary Western Europe', in Coakley, John (ed.), The Social origins of Nationalist Movements, (London: SAGE/ECPR, 1992), pp. 212-230; and Moreno, Luis, 'Multiple Ethnoterritorial Concurrence in Spain', Nationalism and Ethnic Politics, Vol. 1, No. 1 (1995), pp. 11-32.

${ }^{6}$ Barth, Fredrik (ed.), Ethnic Groups and Boundaries. The Social Organization of Culture Difference (Boston: Little, Brown \& Co, 1969).

7 Anderson, Benedict (1983), Imagined Communities: Reflections on the Origins and Spread of Nationalism (London: Verso, 1983). Se also Hobsbawm, Eric (1990), Nations and Nationalism since 1780: Programme, Myth and Reality (Cambridge: Cambridge University Press, 1990); Brass, Paul, Ethnicity and Nationalism. Theory and Comparison (New Delhi: Sage, 1991); and Cohen, Anthony (1992), The Symbolic Construction of Community (1st Ed.: 1985. London: Routledge, 1992).

8 The persistence of a dual identity or compound nationality in Spain is indicative of their internal ethnoterritorial relations. According to Juan Linz, "Spain ... is a state for all Spaniards, a nation-state for a large part of the Spanish population, and only a state but not a nation for important minorities" ('Politics in a Multi-Lingual Society with a Dominant World Language: The case of Spain', in Jean-Guy Savard and Richard Vigneault (eds.), Les états multilingues: problems et solutions (Québec: Les Presses de l'Université Laval, 1975, p. 423). On the Spanish case, see Moreno, Luis (1997a), La federalización de España. Poder político and territorio (Madrid: Siglo XXI, 1997), and Moreno, Luis (1997b), Federalism: The Spanish Experience (Pretoria: HRSC, 1997).

${ }^{9}$ The example of Spain is illustrative. In all seventeen Spanish Comunidades Autónomas (regions and nationalities) there is a high proportion of citizens who claim some form of dual identity. The question addressed to them in the successive polls was as follows: 'In general, would you say that you feel...(1) 'Only Andalusian, Basque, Catalan, etc.'; (2) 'More Andalusian, Basque, Catalan, etc. than Spanish'; (3) 'As much Andalusian, Basque, Catalan as Spanish'; (4) 'More Spanish than Andalusian, Basque, Catalan, etc.'; or (5) 'Only Spanish'. In the period October 1990-June 1995 a degree of duality was expressed by around 70 per cent of the total Spanish population (i.e. categories 2, 3 and 4). Approximately 30 per cent of all Spaniards expressed a single identity ('Only Spanish', or 'Only Andalusian, Basque, Catalan, etc.'). For an analysis of the case of Catalonia see Moreno, Luis and Ana Arriba, 'Dual Identity in Autonomous Catalonia', Scottish Affairs, No. 17 (1996), pp. 78-97, and Moreno, Luis; Arriba, Ana, and Araceli Serrano, 'Multiple Identities in Decentralized Spain: The Case of Catalonia', Regional and Federal Studies, Vol.,. 8, No.3 (1998), pp 65-88.

${ }^{10}$ For William Safran, one of the prominent characteristics of American social science in general, and the behaviorist-functionalist school of political science in particular, is its ahistoricist bias. History is rejected on two grounds: "First...as a succession of events that...do not lend themselves to comparison and generalization...Second...because it is associated with pre-modern (primitive) societies..." ('Ethnic Mobilization, Modernization, and Ideology: Jacobinism, Marxism, Organicism and Functionalism', The Journal of Ethnic Studies, Vol. 15, No. 1(1987), p. 13). 'Mainstream' Marxists have traditionally taken a functional approach to the analysis of political integration and modernization. See Connor, Walker, The National Question in Marxist-Leninist Theory and Strategy (Princeton, N.J.: Princeton University Press, 1984).

11 The cases of Catalonia and Scotland in Europe and Quebec in North America are paradigmatic in this respect. See, for example, Keating, Michael (1996), Nations Against the State: The New Politics of Nationalism in Quebec, Catalonia and Scotland (London: Macmillan, 1996). See also Conversi, Daniele (1997), The Basques, The Catalans and Spain. Alternative Routes to Nationalist Mobilisation (London: C. Hurst \& Co, 1997) and Gagnon, Alain-G. (ed.), Quebec: State and Society (Scarborugh, Ont.: Nelson, 1993).). 
12 See, for example, Dahl, Robert, Polyarchy, Participation and Opposition (New Haven, Conn.: Yale University Press, 1971), and Horowitz, Donald, Ethnic Groups in Conflict (Berkeley, CA.: University of California Press, 1985). Robert Dahl's position is in line with the views of Ernest Baker who also regarded political secessionism and authoritarianism as the two viable options in ethnocultural polyarchies.

${ }^{13}$ Tamir, Yael, Liberal Nationalism (Princeton, N.J.: Princeton University Press, 1993).

${ }^{14}$ On multiculturalism see Taylor, Charles, Multiculturalism and 'The Politics of Recognition': an essay (Princeton, N.J.: Princeton University Press, 1992), and Walzer, Michael (1997), On toleration (New Haven, Conn.: Yale University Press, 1997).

${ }^{15}$ For Will Kymlicka ethnoterritorial accommodation would not constitute a stable political solution but a previous step to secession ('Federalismo, Nacionalismo y Multiculturalismo', Revista Internacional de Filosofía Política No. 7 (1996), p. 45). However, in a subsequent writing Kymlicka shows that it would be a misrepresentation to characterize him as being pessimistic about the viability of multinational federations (Finding our Way: Rethinking Ethnocultural Relations in Canada, Oxford : Oxford University Press, 1998). Juan Linz's views are that federalism can consolidate liberal democracy in multinational states (Linz, Juan ('Democracy, multinationalism and federalism'. Paper resented at the IPSA World Congress, Seoul).

${ }^{16}$ Marxist thinkers would use concepts such as 'class consciousness' and 'class struggle'. For both schools of thought, however, political integration and state building were the independent variables in a social analysis where culture and language were dependent categories.

17 Koelble, Thomas, 'The New Institutionalism in Political Science and Sociology', Comparative Politics, Vol. 27, No. 2 (1995), pp. 231-243.

18 This is particularly relevant as regards major conurbations, regions, stateless nations, and small nation-states. Greater London, the North East of England, Scotland, and the Republic of Ireland are instances of such communities in the context of the British Isles.

${ }^{19}$ McLuhan, Marshall (1964), Understanding Media. The Extensions of Man (New York: McGraw-Hill, 1964) and McLuhan, Marshall and Fiore, Quentin, The Medium is the Massage. An Inventory of Effects (New York: Bantam Books, 1967).

${ }^{20}$ Castells, Manuel, The Information Age: Economy, Society and Culture. Volume II: The Power of Identity (Cambridge, Mass.: Blackwell, 1997).

${ }^{21}$ Sartori, Giovanni, Homo videns (Rome: Gius, Laterza \& Figli Spa, 1997)..

22 Schmidt, Vivien, 'The New World Order, Incorporated: The Rise of Business and the Decline of the Nation-State", What Future for the State?, Daedalus, Vol. 124, No. 2 (1995), pp. 75-106.

${ }^{23}$ Besides, the informal sector of the international economy counts on the financial connivance of some transnational networks for the 'whitening' of the profits of the illegal drug trade.

${ }^{24}$ Boeing, for instance, decided to drop its labeling as an 'American corporation'. Note that many of the components for their planes are produced in a dozen different countries outside the USA. Other companies take advantage of being a multinational consortium, as is the case of Airbus, the commercial rival of Boeing.

${ }^{25}$ According to some authors, capital movements only take into account the potential level of profits disregarding geographical criteria; see Greider, William (1997), One World, Ready or Not: The Manic Logic of Global Capitalism (New York. Simon \& Schuster, 1997). . However, the economic crises in Japan and South East Asia in the late 1990s seem to corroborate the axiom that the international financial markets are unstable by nature.

${ }^{26}$ A different issue is the location of central bureaucracies (or 'eurocracies', as is the case of Brussels) in their territories. Some of the officials of the central institutions cannot refrain from the perception that capital cities are the very representation of the nation-state.

${ }^{27}$ Etzioni, Amitai, The Spirit of Community. Rights, Responsibilities, and the Communitarian Agenda (New York: Crown, 1993).

${ }^{28}$ Other functional identities linked to various dimensions of social life, such as cultural forms, gender, religion and individual sociobiological conditions can also be interpreted as new forms of 'resistance'; 
see Kilminster, Richard, 'Globalization as an Emergent Concept', in Alan Scott (ed.), The Limits of Globalization. London: Routledge, 1997), pp. 257-283.

${ }^{29}$ De-naturalizing is used here to mean the deprivation of the rights of citizenship within an established democratic polity.

${ }^{30}$ According to Manuel Castells, op. cit., note 20, 'project identities' do not seem to originate from the old identities of the civil societies in the Industrial Age, but from the development of current 'resistance identities' against the informational avalanche. This argument is rather circular as regards its territorial dimension. In the case of the USA sub-state spatial identities are not commensurable with the type of identities deeply rooted in the Volkgeist of the diverse European peoples.

${ }^{31}$ See, for instance, Deacon, Bob; Husle, Michelle and Paul Stubbs (1997), Global Social Policy. International Organizations and the Future of Welfare (London: Sage, 1997).

${ }^{32}$ Chomsky, Noam, World Orders, Old and New (London: Pluto, 1994). 